\title{
Combining Ability Studies for Earliness and Determinate Trait in Genetically Diverse Lines of Ricebean [Vigna umbellata (Thunb.) Ohwi and Ohashi]
}

\author{
Tanuja Kapoor and Neelam Bhardwaj*
}

Department of Organic Agriculture, CSKHPKV, Palampur-176062, India

*Corresponding author

\begin{abstract}
A B S T R A C T
Keywords

Combining ability,

Ricebean, Vigna

umbellata, Earliness

and determinate trait

Article Info

Accepted:

10 March 2018

Available Online:

10 April 2018

Six genotypes as lines and two genotypes as testers of ricebean were studies in line $\mathrm{x}$ tester analysis. The study revealed that the gene action involved in controlling characters namely, days to flowering, days to maturity, plant height, branches per plant, pods per plant, clusters per plant, pods per cluster, seeds per pod and yield per plant was nonadditive gene action while two traits namely, 100-seed weight and pod length was under the control of additive gene action. Genotype RBHP-38 and RBHP-43 were found to be good general combiner for earliness and for determinate habit RBHP-38 and RBHP-108 were found to be top ranking general combiners. None of the testers found good general combiner for all the characters. The cross RBHP-36 x PRR-2007-2 recorded significant negative sca effects for days to flowering, days to maturity and plant height indicating earliness and determinate habit. The crosses RBHP-36 x RBHP-900 and RBHP-61 x PRR2007-2 recorded positive significant positive sca effects for branches per plant, pods per plant, clusters per plant, pods per cluster and yield per plant. These crosses could be further exploited to obtain transgressive_segregants in the breeding programme.
\end{abstract}

\section{Introduction}

Ricebean [Vigna umbellata (Thunb.) Ohwi and Ohashi] is one of such underutilized warm season annual vine legume with diploid chromosome number $(2 \mathrm{n}=2 \mathrm{x}=22)$ which belong to subgenus Ceratotropus in the genus Vigna. It is a vital source of protein, especially for the poor who often cannot afford animal products. These crops also contain high amounts of macro and micronutrients $(\mathrm{Ca}, \mathrm{P}$, $\mathrm{K}, \mathrm{Fe}$ and $\mathrm{Zn}$ ), vitamins (niacin, Vitamin $\mathrm{A}$, Ascorbic Acid, Inositol), fibre and carbohydrate for balanced nutrition. Its wild progenitor is V. umbellata var. Gracilis with which it is cross fertile (Tomooka et al., 1991). Study of heterosis in ricebean is important for the plant breeder to find out the superior crosses.

However, success depends primarily upon identification of best parental lines which may produce desirable gene combinations. The knowledge of gene action and combining ability helps in the selection of suitable parents for hybridization and $F_{1}$ 's for identification of transgressive segregants for further exploitation in breeding programmes. 
The present study was therefore, carried out to know the type of gene action and combining ability for earliness and determinate traits.

\section{Materials and Methods}

The experimental material consists of $12 \mathrm{~F}_{1}$ 's of ricebean involving six high yielding but indeterminate genotypes; RBHP-36, RBHP38, RBHP-43, RBHP-61, RBHP-107 and RBHP-108 and two early and determinate genotypes as testers; PRR-2007-2 and RBHP900. These 20 genotypes (12 $\mathrm{F}_{1}$ 's and 8 parents) were sown in kharif 2016 in randomized block design with three replications and each genotype was sown in 1 $\mathrm{m}$ long single row spaced $30 \mathrm{~cm}$ apart. Within rows seeds were sown at $10 \mathrm{~cm}$ distance. Observations were recorded on five randomly selected plants from each $\mathrm{F}_{1}$ and parents on twelve quantitative traits viz., days to $50 \%$ flowering, days to $75 \%$ maturity, plant height (cm), branches per plant, pods per plant, clusters per plant, pods per cluster, seeds per pod, 100-seed weight $(\mathrm{g})$, pod length $(\mathrm{cm})$ and yield per plant $(\mathrm{g})$. The statistical analysis was done as per procedure given by Kempthrone (1957) for heterosis and combining ability analysis.

\section{Results and Discussion}

The analysis of variance for general (gca) and specific (sca) combining ability for various traits are presented in Table 1.The variance due to lines was significant for all the traits whereas variance due to tester was significant for all traits except branches per plant. The variance due to lines $\mathrm{x}$ testers was highly significant for all the traits. The significant differences among different genotypes of urdbean and their $F_{1}$ hybrids for grain yield and other component traits in different sets of material were also reported by Purohit et al., (2016), Kujur and Lavanya (2011) and Gill (2014).
The relative estimates of variance due to sca were higher than variance due to gca. The preponderance of additive type of gene action was registered by 100-seed weight and pod length. Maximum values of $\sigma^{2}$ gca were negative indicated no role of this component of variance in the inheritance while the positive value of $\sigma^{2}$ sca indicated the importance of non-additive gene action. The predominance of non-additive gene action brought out that this component could be exploited in hybrid development. Purohit et al., (2016) recorded the predominance of nonadditive gene action for all the characters under study in urdbean. Bainade et al., (2014) also observed negative values for $\sigma^{2}$ gca or additive variance for days to $50 \%$ flowering, days to maturity, number of primary branches per plant and number of seeds/pod in green gram. However, Singh et al., (2003) reported the importance of both additive and nonadditive components for plant height and grain yield per plant in urdbean.

The estimates of GCA of parents are given in Table 2. The parents with significant gca effects are considered as good general combiners for deriving desirable transgressive segregants in self-pollinated crops. However for certain traits like days to maturity and flowering and plant height negative gca effects are desirable. In the present study significant negative GCA effects were observed for RBHP-38 and RBHP-43 for days to flowering and days to maturity. In case of days to flowering, genotype RBHP-43 was observed to be the best general combiner as it showed the highest significant negative GCA effect. In case of days to maturity, genotype RBHP-38 was the best general combiner as it showed the highest negative GCA effects. The female RBHP-43 was also observed a good general combiner for maturity indicated superiority of these parents in transmitting desirable gene for earliness and maturity to their descendants. For plant height, highest negative GCA effects 
were observed for RBHP-38 followed by RBHP-108. Among the testers, RBHP-900 showed negative but non-significant GCA effect for days to flowering. PRR-2007-2 showed significant negative GCA effect for days to maturity and found to be best combiner. For plant height, highest negative GCA effect was observed for RBHP-900. For all the three traits viz., days to flowering, maturity and plant height RBHP-38 and was found to be the best general combiner.

In case of branches per plant which is an important yield contributing trait, the best combiner was RBHP-107 and other female parents having positive GCA effect was RBHP-43. Number of pods per plant has a direct bearing on the total productivity of rice bean. Keeping this in view, three lines were identified as best general combiner, viz., RBHP-108 followed by RBHP-36 and RBHP43. For cluster per plant, best general combiner was RBHP-108. For pods per cluster best general combiner was RBHP-61. For seeds per pod best general combiner line was RBHP-107 followed by RBHP-36. In case of 100 -seed weight, the best combiner was RBHP-38 and for pod length three lines, viz., RBHP-107 and RBHP-36 were adjudged as the best general combiners on the basis of their significant positive GCA effects. For seed yield per plant, there was only one line which showed significant positive general combining ability effects, viz., RBHP-61. Other female parents, which had positive, though, non-significant GCA effects were RBHP-43 followed by RBHP-36 and were the average general combiner. PRR-2007-2 showed significant positive GCA effect for three traits, viz., pods per plant, clusters per plant and 100-seed weight. RBHP-900 showed significant positive GCA effect for two traits, viz., pods per cluster and pod length. The similar type of results also reported by Patel $e t$ al., (2010), Yadav and Lavanya (2011), Sujata and Kajjidoni (2013), Bainade et al., (2014) and Vaidya et al., (2015)

Table.1 Analysis of variance for combining ability for various characters

\begin{tabular}{|c|c|c|c|c|c|c|c|c|}
\hline $\begin{array}{l}\text { Source of } \\
\text { variation }\end{array}$ & & Lines & Testers & $\begin{array}{l}\text { Lines } \mathbf{x} \\
\text { Testers }\end{array}$ & Error & $\sigma^{2} \mathrm{gca}$ & $\sigma^{2} \mathrm{sca}$ & $\begin{array}{l}\sigma^{2} \mathrm{gca} / \\
\sigma^{2} \mathrm{sca}\end{array}$ \\
\hline Traits & df & 5 & 1 & 5 & 22 & & & \\
\hline $\begin{array}{c}\text { Days to } \\
\text { flowering }\end{array}$ & & $31.400 *$ & $9.000 *$ & $58.933^{*}$ & 2.053 & -0.6514 & 18.96 & -0.0343 \\
\hline $\begin{array}{l}\text { Days to } \\
\text { maturity }\end{array}$ & & $389.333 *$ & $386.777^{*}$ & $473.977 *$ & 4.340 & -1.7723 & 156.54 & -0.0113 \\
\hline Plant height & & $\begin{array}{c}1201.109 \\
*\end{array}$ & $525.173^{*}$ & $1447.93^{*}$ & 37.630 & -7.4892 & 470.1 & -0.0159 \\
\hline $\begin{array}{c}\text { Branches per } \\
\text { plant }\end{array}$ & & $0.265^{*}$ & 0.027 & $0.750 *$ & 0.023 & -0.0109 & 0.24 & -0.0454 \\
\hline $\begin{array}{c}\text { Pods per } \\
\text { plant }\end{array}$ & & $108.568^{*}$ & $156.333^{*}$ & $191.243^{*}$ & 1.297 & -1.5565 & 63.3 & -0.0245 \\
\hline $\begin{array}{c}\text { Clusters per } \\
\text { plant }\end{array}$ & & $6.241^{*}$ & $251.328^{*}$ & $61.899 *$ & 0.188 & -0.3086 & 20.57 & -0.0150 \\
\hline $\begin{array}{l}\text { Pods per } \\
\text { cluster }\end{array}$ & & $0.199 *$ & $1.006^{*}$ & $1.813^{*}$ & 0.042 & -0.0308 & 0.59 & -0.5220 \\
\hline Seeds per pod & & $1.917^{*}$ & $1.604 *$ & $2.041 *$ & 0.220 & -0.0037 & 0.60 & -0.0061 \\
\hline $\begin{array}{l}\text { 100-seed } \\
\text { weight }\end{array}$ & & $1.549^{*}$ & $4.389^{*}$ & $1.352 *$ & 0.062 & 0.0140 & 0.43 & 3.91 \\
\hline Pod length & & $4.650^{*}$ & 5.994* & $2.143 *$ & 0.292 & 0.0569 & 0.61 & 2.33 \\
\hline $\begin{array}{c}\text { Yield per } \\
\text { plant }\end{array}$ & & $7.511^{*}$ & 7.493* & $24.698 *$ & 1.890 & -0.3581 & 7.60 & -0.0471 \\
\hline
\end{tabular}


Table.2 Estimates of general combining ability (gca) effects of the parents for various characters

\begin{tabular}{|c|c|c|c|c|c|c|c|c|c|c|c|}
\hline Lines & $\begin{array}{l}\text { Days to } \\
\text { flowering }\end{array}$ & $\begin{array}{l}\text { Days to } \\
\text { Maturity }\end{array}$ & Plant height & $\begin{array}{c}\text { Branches per } \\
\text { plant }\end{array}$ & $\begin{array}{l}\text { Pods per } \\
\text { plant }\end{array}$ & $\begin{array}{c}\text { Clusters per } \\
\text { plant }\end{array}$ & $\begin{array}{l}\text { Pods per } \\
\text { cluster }\end{array}$ & $\begin{array}{c}\text { Seeds per } \\
\text { pod }\end{array}$ & $\begin{array}{c}\text { 100-seed } \\
\text { weight }\end{array}$ & Pod length & $\begin{array}{c}\text { Yield per } \\
\text { plant }\end{array}$ \\
\hline RBHP-36 & 0.17 & $3.00 *$ & -0.96 & $-0.21 *$ & $1.85^{*}$ & 0.16 & 0.11 & $0.56^{*}$ & -0.02 & $0.74 *$ & 0.86 \\
\hline RBHP-38 & $-1.50 *$ & $-8.33 *$ & $-20.00 *$ & $-0.24 *$ & $-7.02 *$ & $-1.57 *$ & -0.16 & 0.06 & $1.00 *$ & $-0.93^{*}$ & -0.72 \\
\hline RBHP-43 & $-2.50 *$ & $-6.00 *$ & $15.55^{*}$ & $0.16 *$ & $1.48 *$ & $-0.54^{*}$ & 0.00 & -0.16 & -0.07 & $-1.16^{*}$ & 0.76 \\
\hline RBHP-61 & 0.17 & -1.33 & $10.90 *$ & -0.11 & $-1.81^{*}$ & 0.15 & $0.30 *$ & -0.09 & $-0.34 *$ & 0.39 & $1.24 *$ \\
\hline RBHP-107 & -0.50 & $14.33^{*}$ & $7.84^{*}$ & $0.26 *$ & -0.18 & 0.26 & -0.10 & $0.58 *$ & $-0.36^{*}$ & $0.99 *$ & 0.53 \\
\hline RBHP-108 & $4.17 *$ & -1.67 & $-13.33^{*}$ & 0.13 & $5.68 *$ & $1.53 *$ & -0.16 & $-0.96^{*}$ & -0.21 & -0.03 & $-1.61 *$ \\
\hline $\mathrm{SE}(\mathrm{gi}) \pm$ & 0.58 & 0.85 & 2.50 & 0.06 & 0.46 & 0.17 & 0.08 & 0.19 & 0.10 & 0.22 & 0.56 \\
\hline SE(gi-gj) \pm & 0.82 & 1.20 & 3.54 & 0.08 & 0.65 & 0.25 & 0.11 & 0.27 & 0.14 & 0.31 & 0.79 \\
\hline \multicolumn{12}{|l|}{ Testers } \\
\hline PRR-2007-2 & 0.50 & $-3.28 *$ & $3.82 *$ & 0.03 & $2.08 *$ & $2.64 *$ & $-0.17^{*}$ & -0.21 & $0.35 *$ & $-0.41^{*}$ & 0.46 \\
\hline RBHP-900 & -0.50 & $3.28 *$ & $-3.82 *$ & -0.03 & $-2.08 *$ & $-2.64 *$ & $0.17 *$ & 0.21 & $-0.35^{*}$ & $0.41 *$ & -0.46 \\
\hline $\mathrm{SE}(\mathrm{gi}) \pm$ & 0.33 & 0.49 & 1.44 & 0.03 & 0.26 & 0.10 & 0.04 & 0.11 & 0.05 & 0.12 & 0.32 \\
\hline SE(gi-gk) \pm & 0.47 & 0.69 & 2.04 & 0.05 & 0.37 & 0.14 & 0.06 & 0.15 & 0.08 & 0.18 & 0.45 \\
\hline
\end{tabular}

Table.3 Estimates of SCA effects of different cross combinations for various characters

\begin{tabular}{|c|c|c|c|c|c|c|c|c|c|c|c|}
\hline Crosses & $\begin{array}{l}\text { Days to } \\
\text { flowering }\end{array}$ & $\begin{array}{c}\text { Days to } \\
\text { Maturity }\end{array}$ & $\begin{array}{c}\text { Plant } \\
\text { height }\end{array}$ & $\begin{array}{l}\text { Branches } \\
\text { per plant }\end{array}$ & $\begin{array}{c}\text { Pods per } \\
\text { plant }\end{array}$ & $\begin{array}{c}\text { Clusters } \\
\text { per plant }\end{array}$ & $\begin{array}{l}\text { Pods per } \\
\text { cluster }\end{array}$ & $\begin{array}{c}\text { Seeds per } \\
\text { pod }\end{array}$ & $\begin{array}{c}100 \text {-seed } \\
\text { weight }\end{array}$ & $\begin{array}{c}\text { Pod } \\
\text { length }\end{array}$ & $\begin{array}{c}\text { Yield per } \\
\text { plant }\end{array}$ \\
\hline RBHP-36 X PRR-2007-2 & $-4.33 *$ & $-12.72 *$ & $-20.54 *$ & $-0.56^{*}$ & $-9.75^{*}$ & $-5.74 *$ & $-0.30 *$ & 0.31 & 0.25 & -0.02 & $-3.80 *$ \\
\hline RBHP-36 X RBHP-900 & $4.33 *$ & $12.72 *$ & $20.54^{*}$ & $0.56^{*}$ & $9.75^{*}$ & $5.74 *$ & $0.30 *$ & -0.31 & -0.25 & 0.02 & $3.80 *$ \\
\hline RBHP-38 X PRR-2007-2 & -1.33 & -1.06 & 1.18 & $0.41 *$ & -0.96 & $0.99 *$ & 0.10 & -0.46 & $0.31 *$ & -0.21 & 0.88 \\
\hline RBHP-38 X RBHP-900 & 1.33 & 1.06 & -1.18 & $-0.41 *$ & 0.96 & $-0.99 *$ & -0.10 & 0.46 & $-0.31 *$ & 0.21 & -0.88 \\
\hline RBHP-43 X PRR-2007-2 & 0.00 & $6.28 *$ & 4.78 & -0.06 & $3.88 *$ & $1.02 *$ & 0.10 & 0.53 & -0.13 & $0.83 *$ & 0.87 \\
\hline RBHP-43 X RBHP-900 & 0.00 & $-6.28 *$ & -4.78 & 0.06 & $-3.88^{*}$ & $-1.02 *$ & -0.10 & -0.53 & 0.13 & $-0.83 *$ & -0.87 \\
\hline RBHP-61 X PRR-2007-2 & 0.33 & $5.94 *$ & 6.74 & $0.34 *$ & $4.18 *$ & $3.41 *$ & $0.83 *$ & -0.37 & $-0.39 *$ & 0.36 & $2.15 *$ \\
\hline RBHP-61 X RBHP-900 & -0.33 & $-5.94 *$ & -6.74 & $-0.34 *$ & $-4.18 *$ & $-3.41 *$ & $-0.83 *$ & 0.37 & $0.39 *$ & -0.36 & $-2.15 *$ \\
\hline RBHP-107X PRR-2007-2 & 0.00 & $-8.06 *$ & $22.42 *$ & 0.04 & $5.02 *$ & $1.72 *$ & 0.10 & $0.69 *$ & $0.61 *$ & -0.00 & -0.09 \\
\hline RBHP-107 X RBHP-900 & 0.00 & $8.06 *$ & $-22.42 *$ & -0.04 & $-5.02 *$ & $-1.72 *$ & -0.10 & $-0.69 *$ & $-0.61 *$ & 0.00 & 0.09 \\
\hline RBHP-108 X PRR-2007-2 & $5.33 *$ & $9.61 *$ & $-14.58 *$ & -0.16 & $-2.37 *$ & $-1.41 *$ & $-0.83 *$ & $-0.71 *$ & $-0.65 *$ & $-0.96 *$ & -0.01 \\
\hline RBHP-108 X RBHP-900 & $-5.33 * *$ & $-9.61 *$ & $14.58^{*}$ & 0.16 & $2.37 *$ & $1.41 *$ & $0.83 *$ & $0.71 *$ & $0.65 *$ & $0.96^{*}$ & 0.01 \\
\hline SE (Sij) \pm & 0.82 & 1.20 & 3.54 & 0.08 & 0.65 & 0.25 & 0.11 & 0.27 & 0.14 & 0.31 & 0.79 \\
\hline SE (Sij-Skl) \pm & 1.16 & 1.70 & 5.00 & 0.12 & 0.93 & 0.35 & 0.16 & 0.38 & 0.20 & 0.44 & 1.12 \\
\hline
\end{tabular}


Table.4 List of good general combiners for different traits

\begin{tabular}{|l|l|l|}
\hline Traits & Lines & Testers \\
\hline Days to flowering & RBHP-43 and RBHP-38 & None \\
\hline Days to Maturity & RBHP-43 and RBHP-38 & PRR-2007-2 \\
\hline Plant height & RBHP-38 and RBHP-108 & RBHP-900 \\
\hline Branches per plant & RBHP-107 and RBHP-43 & None \\
\hline Pods per plant & RBHP-108, RBHP-36 and RBHP-43 & PRR-2007-2 \\
\hline Clusters per plant & RBHP-108 & PRR-2007-2 \\
\hline Pods per cluster & RBHP-61 & RBHP-900 \\
\hline Seeds per pod & RBHP-107 and RBHP-36 & None \\
\hline 100-seed weight & RBHP-38 & PRR-2007-2 \\
\hline Pod length & RBHP-107 and RBHP-36 & RBHP-900 \\
\hline Yield per plant & RBHP-61 & None \\
\hline
\end{tabular}

Table.5 List of cross combinations showing good specific combining ability (SCA) effects for different traits

\begin{tabular}{|l|l|}
\hline \multicolumn{1}{|c|}{ Traits } & \multicolumn{1}{|c|}{ Cross combination } \\
\hline Days to flowering & RBHP-108 x RBHP-900 and RBHP-36 x PRR-2007-2 \\
\hline Days to Maturity & RBHP-36 x PRR-2007-2 \\
\hline Plant height & RBHP-107 x RBHP-900, RBHP-36 x PRR-2007-2 and RBHP-108 xPRR-2007-2 \\
\hline Branches per plant & RBHP-36 x RBHP-900, RBHP-38 x PRR-2007-2 and RBHP-61 xPRR-2007-2 \\
\hline Pods per plant & $\begin{array}{l}\text { RBHP-36 x RBHP-900, RBHP-61 x PRR-2007-2, RBHP-43 x PRR-2007-2 and } \\
\text { RBHP-108 x RBHP-900 }\end{array}$ \\
\hline Clusters per plant & $\begin{array}{l}\text { RBHP-36 x RBHP-900, RBHP-108 x RBHP-900, RBHP-107 xPRR-2007-2, } \\
\text { RBHP-61 x PRR-2007-2, RBHP-43 x PRR-2007-2 and RBHP-38 x PRR-2007-2 }\end{array}$ \\
\hline Pods per cluster & RBHP-108 x RBHP-900, RBHP-61 x PRR-2007-2 and RBHP-36 x RBHP-900 \\
\hline Seeds per pod & RBHP-108 x RBHP-900 and RBHP-107 x PRR-2007-2 \\
\hline 100-seed weight & RBHP-108 x RBHP-900, RBHP-107 x PRR-2007-2, RBHP-61 x RBHP-900 and \\
\hline PBHP-38 v PRR-2007-2
\end{tabular}

In present investigation, the good general combiners with respect to different traits indicated that no single parent was proved to be a good general combiner for all the traits. Line 'RBHP-43' was found to be a good general combiner for days to flowering, days to maturity, branches per plant and pods per plant. Likewise line RBHP-38 was found to be good general combiner for most of the traits, viz., days to flowering, days to maturity, plant height and 100-seed weight. Line RBHP-107 was found to be good general combiner for number of branches, seeds per pod and pod length while the line RBHP-108 was found to be good general combiner for pods per plant, number of clusters and plant height. RBHP-61 was found to be good general combiner for pods per cluster and yield per plant. RBHP-36 was found to be good general combiner for pods per plant, seeds per pod and pod length.

Tester PRR-2007-2 was found to be good general combiner for days to maturity, pods per plant, number of clusters and 100-seed weight and RBHP-900 was found to be good general combiner for plant height, pods per cluster and pod length. On the basis of the performance of parents with respect to GCA effects for different traits, it can be concluded 
that line RBHP-43, RBHP-38 was found to be good general combiner for four traits followed by RBHP-108, RBHP-107 and RBHP-36 for three traits followed by RBHP61 for two traits. The high GCA effects are associated with additive and additive $\mathrm{x}$ additive interaction effects (Griffing, 1956) hence, these good general combiners can be used in the varietal improvement programme.

The SCA effect is an important criterion for the evaluation of hybrids. Among the various gene interactions contributing towards SCA, the additive $x$ additive type of gene interaction is fixable in later generations in self-pollinated crops. Thus, the ultimate aim of a breeder is to generate desirable transgressive segregants to develop potential homozygous lines through hybridization. The cross combinations with significant desirable SCA effects along with GCA effects of the parents for various traits are listed in Table 3. The cross RBHP-36 x PRR-2007-2 recorded significant negative SCA effects for days to flowering, days to maturity and plant height indicated the best specific combiner for earliness and determinate trait. The crosses RBHP-36 x RBHP-900 and RBHP-61 x PRR2007-2 recorded positive significant positive SCA effects for branches per plant, pods per plant, clusters per plant, pods per cluster and yield per plant. The crosses RBHP-108 x RBHP-900 and RBHP-40 x PRR-2007-2 recorded positive significant positive SCA effects for pods per plant, clusters per plant and pod length. RBHP-107 x PRR-2007-2 and RBHP-38 $x$ PRR-2007-2 recorded significant positive SCA effects for clusters per plant and 100-seed weight. The results were in accordance with Patil et al., (2011), Sujata and Kajjidoni (2013), Patil et al., (2014) and Vaidya et al., (2015).

It was observed that the desirable cross combination included high $\mathrm{x}$ high, medium $\mathrm{x}$ high, high $\mathrm{x}$ low, medium $\mathrm{x}$ medium and low $\mathrm{x}$ low type of general combiner (Gill et al., 2014). The high $x$ medium or vice-versa combination could be due to additive and additive $\mathrm{x}$ additive type of gene action which is fixable in nature. The desirable performance of cross combination like low $\mathrm{x}$ medium, medium $\mathrm{x}$ medium general combiners may be ascribed to complimentary gene effects. The present study described the importance of both additive and non-additive components of inheritance in ricebean. Since the main aim was to identify best parents for incorporating earliness and determinate habit, hence parents RBHP-38, RBHP-43, RBHP400 and PRR-2007-2 were found best general combiners for the trait of interest while the cross RBHP-36 x PRR-2007-2 recorded significant negative SCA effects for days to flowering, days to maturity and plant height indicated the best specific combiner for earliness and determinate trait.

\section{Authors' Contributions}

Both the authors have equal contribution in the research work mentioned in the paper and the paper is written by both of them.

\section{References}

Bainade, P. S, Manjare M. R., Deshmukh S. G. and Kumbhar S. D. 2014.Genetic analysis in green gram (Vigna radiata (1.)Wilczek) subjected to North Carolina mating design-I. The Bioscan, 9: 875878

Gill, R.K., Singh I., Singh S. and Singh P. 2014. Studies on combining ability for grain yield and component traits in Kharif urdbean. Legume Research 37: 575-579

Griffing, B. 1956. Concepts of general and specific combining ability in relation to diallel crossing systems. Australian Journal of Biological Sciences 9: 436493. 
Kempthorne, O. 1957. An Introduction to Genetic Statistics. John Wiley and Sons, New York, 458- 471

Kujur, S. N. and Lavanya G. R. 2011.Combining ability studies in mungbean. Journal of Food Legume 24: 239-241.

Panse, V.G. and Sukhatme P.V. 1984. Statistical Methods for Agricultural Workers. Indian Council of Agricultural Research, New Delhi, 381: 458- 471

Patil, A. B., Desai, N. C., Mule, P. N. and Khandelwal, V. 2011. Combining ability for yield and component characters in mungbean [Vigna radiata (L.) Wilczek]. Legume Research 34: 190-195.

Patil, S. S., Nizama J. R., Jadhav B. D. and Patel S. R. 2014. Heterosis and Combining Ability Studies for Seed Yield and Quality Characters in Genetically Diverse Lines of Mungbean [Vigna radiata (L.) Wilczek]. Indian Journal of Agricultural Research 7: 938-941.

Purohit, Y., Ravindra Babu Y., Gami R. A., Patel M. P., Patel P. T. and Patel A. M.
2016. Combining ability analysis for seed yield, its component and protein content in mungbean (Vigna radiata $\mathrm{L}$. Wilczek). The Bioscan 11: 2981-2985

Singh, M. Sharma, S.K. and Chahota R.K. 2003. Heterosis in urdbean (Vigna mungo (L.) Hepper). Crop Research 26: $131-134$

Sujatha, K. and Kajjidoni S. T. 2013. Genetic Analysis Involving Selected Powdery Mildew Resistant Lines in Mungbean [Vigna radiata L.) Wilczek]. Molecular Plant Breeding 4: doi: 10.5376/ mpb. 2013. 04. 0005.

Vaidya, G. B., Chauhan, D. A., Narwade, A. V., Kale, B. H. and Patil, A. B. 2015. Combining Ability for yield and yield Attributing Characters in Rabi Mungbean [Vigna radiata (L.) Wilczek]. International Journal of Bioresource Science 2: 21-24.

Yadav, P. S. and Lavanya, G. R. 2011. Estimation of combining ability effects in mungbean crosses. [Vigna radiata (L.) Wilczek.]. Madras Agricultural Journal 98: 213-215.

\section{How to cite this article:}

Tanuja Kapoor and Neelam Bhardwaj. 2018. Combining Ability Studies for Earliness and Determinate Trait in Genetically Diverse Lines of Ricebean [Vigna umbellata (Thunb.) Ohwi and Ohashi]. Int.J.Curr.Microbiol.App.Sci. 7(04): 1110-1116.

doi: https://doi.org/10.20546/ijcmas.2018.704.121 